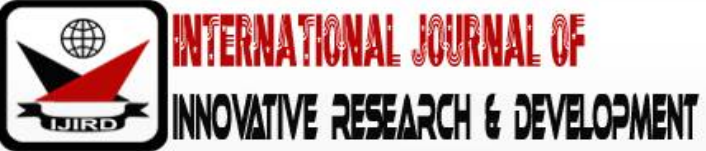

ISSN 2278 - 0211 (Online)

\section{The Effect of Discussion Technique on Academic Achievement in Plant Physiology Course Among NCE II Biology Students of College of Education Gashua, Yobe State, Nigeria}

\begin{tabular}{c} 
Mohammed D. Danladi \\
Principal Lecturer, Department of Biology, \\
Umar Suleiman College of Education Gashua, Nigeria \\
\hline
\end{tabular}

\begin{abstract}
:
The study investigated the effect of Discussion Technique on Academic Achievement in Plant Physiology course among NCE II biology students of College of Education Gashua, Yobe State. Quasi-Experimental and control group design, using pretest and posttest was used for this study. The study used a population of 310 students (139 males and 115 females), and a sample of 80 students ( 40 males and 40 females) was used for the study. The research instrument used for data collection; Plant Physiology Achievement Test (PPAT) was tested for reliability using Kuder-Richardson (KR21) with reliability coefficient of 0.85. T-test statistic was used to identify the difference between the achievements of students exposed to discussion technique and those taught using the traditional lecture method. The result of the study revealed significant difference between the mean academic achievement scores of the experimental and control groups in favour of the experimental group. It is therefore recommended that; i) Discussion technique of teaching should be practiced by science and technology subject teachers, including plant physiology course in biology. ii) There should be in place, training and re-training opportunities for teachers to be effective in their work and carry out their teaching tasks more effectively by employing the use of discussion technique (learner-centered) and reduce over dependence on lecture method (teacher-centered), because the former enhances students' academic achievement while the latter (lecture method) leads to poor achievement.
\end{abstract}

Keywords: Discussion technique, academic achievement, NCE II plant physiology students

\section{Introduction}

The standard of education of any nation depends, to a large extent on the educational background of its teachers and the teaching methodologies they embraced. This because, no educational system could rise above the caliber or quality of its teachers, and the quality of present teachers will invariably reflect in the behavioural disposition of the citizens of tomorrow (NPE, 2004). Because teachers are the instrument for imparting good quality education and functional knowledge to the students, it becomes imperative to give them substantial attention in the country (Ayatse, 2006). Omodara (2012) believed that; the production of good science students in the nation's education institutions revolves around the various techniques of teaching imbibed by the teachers. It then became necessary, as observed by Mfon (2001), to examine some of the techniques and approaches of teaching that are capable of inculcating useful skills and knowledge to the recipients in the teaching-learning process of science in Nigerian schools, to improve the day-to-day academic achievement. There are several teaching techniques/methods as there are teachers, these include; Discussion, Demonstration, Experimental, Expository approach, Discovery, Participatory, among others.

Teaching methods can be said to be the fundamental instruments of education and therefore the nucleus in teaching (Brand, Bennet, Hampden-Thompson, 2013). Omodara (2012) also opined that; methodology is a process of imparting knowledge, ideas and beliefs on a person or group of persons, and it is a general guideline for promoting teaching and learning, which involves various ways of manipulating instructional resources and communication to make the learner receive the teacher's message clearly. Similarly, Omwicheren (2002) believes that; for any teacher to be effective and successful, he must have the ability to pass his knowledge to the learners to bring about the desired behavioural change, thereby enhancing academic achievement.

Academic achievement according to Tomporouski, Philip, Catherine, Patricia and Jack (2008); refers to the extent or manner to which learners, teachers or instructors have achieved their educational goals and objectives through effective measurement and evaluation of a teaching-learning process. The academic achievement of students may also be associated to several factors, such as; family background of parents, peer influence, truancy, teachers' qualification, teaching methods, among others (Vanstumni et'al, 2011). 


\section{Discussion Method}

Discussion teaching technique is a two way interaction between the teacher and students in which the instructional content is discussed in the classroom (Callahan \& Clark, 1979; Ngada, 2007). Discussion according to Aliyu (1982) and Brown (2005) means talking over subjects from various points of view with the teacher acting as the moderator. Atadoga and Onaolopo (2008) viewed discussion method as student - centered focusing on the fact that knowledge arises from within the person and not from external source (Wikianswer, 2011; Olajide, 2002). The authors further elaborated that 'when discussion method is employed, it is mandatory that students have been adequately prepared because it will be ridiculous for a teacher to ask students to discuss a subject or topic or concept about which they know nothing'. Discussion method has imparted positively on the academic achievement of students in sciences due to the following advantages:

- Motivation of students' interest at the beginning of the lesson.

- Develop self-confidence through frequent exchange of ideas between the students and the teacher, thereby improving academic achievement.

- Help students to prepare vigorously before partaking in the discussion process, thus broadening their knowledge and understanding of the instructional content.

- It fosters the development of interpersonal relationship in the class, because the students interact with the teacher and with one another.

- It creates a forum to solve some difficult problems or questions which require a variety of ideas and ways to resolve them among the students.

- It contributes to character development and training for the posts of leadership and responsibility in dealing with people as it encourages the students to accept and tolerate other students' ideas and views.

- It provides opportunities for students to practice and develop oral communication skills.

- It gives students training in searching for facts on their own.

- It encourages students to cultivate scientific attitudes and skills, i.e. listening skills, thinking, analyzing and evaluating points made during discussions.

\subsection{Statement of the Problem}

Some of the major causes of poor academic achievement by students in biology may be associated to the types of teaching methods adopted by teachers, because many teachers, especially higher institutions like Colleges of Education still prefer to use the popular lecture method (Danladi, 2019). However, the problem of ineffective teaching of abstract concepts which consequently leads to poor academic achievement of students can be effectively overcome by using teaching methods that are learner-centered, such as discussion technique among others (Obeka, 2010). In order to overcome the seeming failure in biology education, some research evidences such as that of Usman, Olorukooba and Muonomi (2014) saw the pressing need to reconsider the instructional techniques and methods in Nigerian institutions which foster meaningful learning. Biology curriculum for colleges of Education suggest a shift in methodology from teacher-centered to learner-centered, aimed at engaging learners to explain concepts through effective interaction, and discussion method is an excellent technique for evaluating that. Therefore, this motivated the researcher to investigate on the effect of discussion technique on the academic achievement of NCE II students of plant physiology course.

\subsection{Objective of the Study}

The objectives of the study are;

Determine the effectiveness of discussion technique of teaching plant physiology on academic achievement of NCE II students and those exposed to lecture method.

\subsection{Research Question} students?

What is the effect of discussion technique of teaching on the academic achievement of NCE II plant physiology

\subsubsection{Null Hypothesis}

There is no significant difference in the mean scores of plant physiology students taught using discussion method and those taught the same concept using lecture.

\section{Research Methodology}

Quasi-Experimental research design using pretest and posttest was used for this study. Experimental research design, according to Gribbson, Barry and Harmann (2014) is an empirical study used to estimate the casual impact of an intervention on its target population, and is a type of assessment that aims to investigate whether a programme or intervention has an impact or effect on the participants of the study. Quasi-Experimental design on the other hand is an experimental research design that provides a systematic procedure of identifying and evaluating the relationship between dependent and independent variables that create a particular state of affairs under a controlled condition(s) (Edinyang and Ubi, 2012). Pretest is a situation in which a researcher requires to collect data on study participants' level of performance or achievement before the intervention takes place, while posttest is a situation in which a researcher collect the same data after the intervention has taken place (Gribbson et'al; 2014).The design is illustrated in fig. 1.0: 


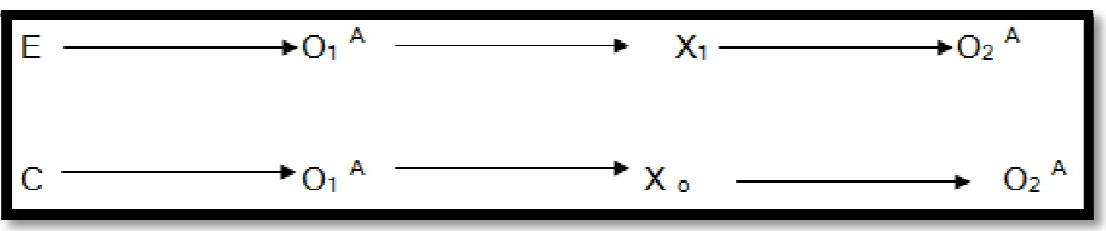

Figure 1: Research Design Illustration

(Experimental-Control Group Design)

Where:

$\mathrm{E}=\quad$ Experimental Group

$\mathrm{C}=\quad$ Control Group

$\mathrm{O}_{1}=$ Pretest

$\mathrm{O}_{2}=\quad$ Posttest

Xo $=\quad$ Lecture Method

$\mathrm{X}_{1}=\quad$ Treatment Group (Discussion Technique)

$\mathrm{A}=$ Evolution Concept Achievement Test (ECAT)

\subsection{Population for the Study}

The population for the study comprised of all NCE II biology students offering plant physiology for 2018/2019 academic session. There are 310 students in all (195 males and 115 girls).

\subsection{Sample and Sampling Procedure}

The sample size used for the study comprised NCE II biology students of plant physiology of Umar Suleiman College of Education, Gashua. Eighty (80) students which included boys and girls out of the 310 were used in both pretest and posttest procedures, in order to measure their academic achievements, using discussion technique of teaching. These students were randomly selected into the two groups. The number of students that serve as sample for the study were selected through simple balloting method, in which the researcher wrote 40 Es and $40 \mathrm{Cs}$ on pieces of papers, shuffle them together and allowed each student to pick one piece of the paper. Those in category ' $E$ ' serve as experimental group, while those in category ' $\mathrm{C}$ ' are the control group. The experimental group is measured for academic achievement using discussion technique, while the control group is measured for the same variables using lecture method. This is in line with the study objective.

\subsection{Research Question} students?

What is the effect of discussion technique of teaching on the academic achievement of NCE II plant physiology

In order to effectively answer the research question for the study, the posttest scores of the students exposed to discussion technique of teaching and that of the control group taught using traditional lecture method were used.

\begin{tabular}{|c|c|c|c|}
\hline Variables & $\mathbf{N}$ & $\mathbf{X}$ & SD $\quad M / D$ \\
\hline Experimental & 40 & 11.70 & $\begin{array}{l}4.6 \\
3.8\end{array}$ \\
\hline Control & 40 & 7.90 & 4.3 \\
\hline
\end{tabular}

Table 1: Mean and Standard Deviation of Posttest Scores of Experimental and Control Group on Achievement

Table 1 showed that the mean score of experimental group exposed to discussion technique of teaching is 11.70 , which is higher than that of the control group taught using lecture method with 7.90. This clearly indicated that discussion technique of teaching proved to be more effective on students' academic achievement over the lecture method.

\subsubsection{Null Hypothesis}

There is no significant difference between the mean scores of students taught using discussion technique of teaching and the academic achievement of NCE II plant physiology students.

In order to test the null hypothesis, t-test analysis was used to compare the posttest scores of students exposed to discussion technique of teaching and those taught the same concept using lecture method, at 0.05 level of significance. The result is presented on Table 2; 


\begin{tabular}{|c|c|c|c|c|c|c|c|c|}
\hline Variables & $\mathbf{N}$ & $\mathbf{X}$ & SD & t-cal. & t-crit. & DF & $\mathbf{P}$ & Remark \\
\hline Experimental & 40 & 11.70 & 4.6 & 12.06 & 6.0 & 78 & 0.00 & Sig. \\
\hline Control & 40 & 7.93 & 4.3 & & & & & \\
\hline
\end{tabular}

Table 2: Effect of Discussion Technique of Teaching on Students' Academic Achievement

Significant $P \leq 0.05$

Table 2 above showed the result of t-test analysis used to test the null hypothesis formulated. From the table, $t-$ calculated is 12.06 which is greater than t-critical, which is 6.0 at 0.05 level of significance. This analysis therefore showed that, discussion technique of teaching has significant effect on the academic achievement of NCE II plant physiology students. Therefore, the null hypothesis which states that; there is no significant difference between the mean scores of NCE II students taught plant physiology concept using discussion technique and those taught the same concept using lecture method was rejected.

\section{Discussion}

The research study revealed that, Discussion Technique of teaching has significantly enhanced the academic achievement of NCE II plant physiology students in College of Education Gashua, Yobe State. This evidence was revealed by the findings on Table 1, which showed the mean scores on achievement of students exposed to discussion method to be 11.70 , which was greater than the mean scores of students who were taught the same concept using lecture method (7.90).

The result of t-test analysis for academic achievement of NCE II plant physiology students was presented in Table 2. The result of t-test analysis on Table 2 revealed that discussion technique had significant effect on the academic achievement of NCE II plant physiology students of College of Education, Gashua. This is because, t-calculated (12.06) was greater than t-critical (6.0) at 0.05 level of significance $(\mathrm{p}=0.05)$. This finding agreed with what obtained by other researchers. The finding on academic achievement agreed with that of Danladi (2014) who found that Socratic discussion enhanced students' performance in evolution concept over the lecture method. Garezynki (2011) also found that students under discussion method achieved higher than those taught using lecture.

\section{Conclusion}

Based on the findings of this study, the following conclusions were drawn; discussion technique of teaching proved to be effective in teaching of plant physiology in college of education Gashua, and therefore enhanced the academic achievement of students.

\section{Recommendations}

Based on the findings and conclusion of the study, the following recommendations were made by the researcher:

- Discussion method of teaching should be practiced by science and technology subject teachers including plant physiology course in biology.

- There should be in place, training and re-training opportunities for teachers to be effective in their work and carry out their teaching tasks more effectively by employing the use of discussion technique (learner-centered) and reduce over dependence on lecture method (teacher-centered), because the former enhances students' academic achievement while the latter (lecture method) leads to poor achievement. However, the result is contrary to the research work of Atadoga and Lakpini (2012), which showed that students taught secondary physics using electric method achieved higher than those taught using discussion method.

\section{References}

i. Anameze, L. (1998). Students Guide to Academic Success. A Handbook on how to study and pass Examination. Uwani, Enugu: CPA and Gold Publishers.

ii. Atadoga, M.M. \& Onaolapo, M.A.O. (2008). A handbook on Science Teaching Methods (I). Nigeria: Shola Press.

iii. Atadoga, M.M. \& Lakpini, M.A. (2012). First AFTRA Teaching and Learning in Africa Conference. An annual International Conference of the African Forum of Teaching Regulatory Authorities. Proceedings Vol.1 85-92

iv. Ayatse, J.Q.I. (2006). Keynote Address in: Ochu, A.O (Ed) Education for National Growth and Stability. Peacemaker, Lagos, Nigeria pp 1-2

v. Braund, M., Bennett, I., Hampden-Thompson, G. (2013). Teaching Approach and Success in Biology: Comparing Students' Attainment in Context-based, Concept-based and Mixed Approaches to Teaching A-Level Biology. Report to the Nuffield Foundation York: Department of Education, University of York. 9 Ann Abor: University Microfilms Abak: BelpotNig.Co.

vi. Brown, C. (2005). Scholarly Articles for Researches Conducted on Discussion Teaching Strategies. Principles of Language Learning and Teaching. 5(2).

vii. Callahan J.E and Clark M.A (1997). Teaching in the elementary school. Planning for competence. London: McMillan Publishing.

viii. $\quad$ Danladi, M.D. (2019). Effect of Socratic Teaching Technique on Performance in Evolution Concept among NCE II Biology Students of College of Education, Gashua, Yobe State, Nigeria. The International Journal of Humanities and Social Studies 7(9):3-5. Retrieved, September, 2019 www.theijhss.com 
ix. Edinyang, S.D. and Ubi, I.E. (2012). Relative Effectiveness of Inquiry and Expository Methods of Teaching Social Studies on Academic Performance of Secondary school Students in Akwa Ibom State, Nigeria. British Journal of Arts and Social Sciences 13(11) http//wwwbjournal.co.uk/BJASS.aspx

X. Federal Ministry of Education. National Policy on Education (1998; 2004). NERDC, Lagos.

xi. Gribbons, I.B., Barry, H. and Harman, D. (2014). The True and Quasi-Experimental Design, Practical Assessment, Research and Evaluation. 5(14), Retrieved, July, 2014 from pareonline.net/getvn.asp/3FV/26

xii. Mfon, E.U. (2011). Effects of Problem-Solving, Guided Discovery and Expository Teaching Strategies on Students' Performance in Redox Reactions. An International Multidisciplinary Journal of Ethiopia, 5(4), 231-241.

xiii. National Commission for Colleges of Education (2008). Minimum Standards for Nigeria Certificate in Education (NCE) (Science and Mathematics) $4^{\text {th }}$ Edition.

xiv. $\quad$ Ngada,A.J. (2008).Principles and Practice of Effective Education. Lagos: Kolas Printing Co.(3), 17-21.

xv. Olajide, J.O. (2002). The Effects of Analogical Reasoning and Extended Wait-Time on Students Achievement and Attitude to Biology. An unpublished Ph.D. Thesis Dept. of Education, A.B.U Zaria.

xvi. Omodara, A.A. (2012). Comparative Analysis of the Effectiveness of Some Teaching Methods in Skill Acquisition by Agricultural Students in Colleges of Education in Kaduna State, Nigeria. Un-published MSc (Ed) Agricultural Education Thesis, Submitted to the Faculty of Education, Ahmadu Bello University, Zaria, Nigeria.

xvii. Omwhiriren, C.M. (2002). The Effect of Guided Discovery and Traditional Methods on the achievement of SSCE Students in the Chemical Energetic. African Journal of Research in Education, 2, 21-24.

xviii. Tomporouski, I., Phillip, P. Catherine, D. Parttricia, M. Jack, N. (2008). Exercise and Children Intelligence, Cognition and Academic Performance and Achievement. Journal of Educational Psychology 2(2): 111-131

xix. Tuckman B.W. (1975). Measuring educational outcomes Handout. New York: Base Huvawick Publhers.

xx. Usman, I.A. (2008). Using a Selected Method of Teaching in Enhancing Slow Learners' Academic Performance Among Senior Secondary School Integrated Science Students.

xxi. Wikianswer, (2011). What are the causes of Good Academic Achievement http://wiki.com/Q/causes of good academic achievement. Retrieved: 11/02/2011.

xxii. Vonstumni, L. Sophie, I., Hell, U., Benedict, J., Chamoro, P., Thomas, K. (2011). The Hungary Mind: Intellectual Curiosity is the Third Pillar of Academic Performance. Perspective on Psychological Science 6(6): 574-588, Retrieved; 11/02/2012 